\title{
Change and Influence in the Community Colleges of British Columbia
}

\author{
JOHN S. LEVIN*
}

\begin{abstract}
During the 1980s, a number of social, economic, and political changes in British Columbia enabled individuals and groups to influence actions which affected the operations and development of the community colleges of British Columbia. This is a study of influence and influencers in the community colleges of British Columbia. Examined are actions affecting the British Columbia community college from 1980-1991. Determinants and outcomes of these actions, as well as those individuals or groups who influenced these actions, are identified.
\end{abstract}

\section{Résumé}

En Columbie-Britannique, au cours des années 80 , divers changements d'ordre social, économique et politique ont permis à certains individus et groupes d'exercer des influences particulières ayant affecté les opérations et le développement des collèges communautaires de la province. On présente ici une étude de ces groupes et de ces influences; on identifie non seulement les causes et les résultats des actions posées durant la période 1980 à 1991, mais aussi les groupes ou les individus ayant exercé une influence particulière dans ce domaine.

* University of Arizona

I am grateful to anonymous reviewers who offered sound advice to strengthen this discussion. I also acknowledge the direction provided by Dr. John Dennison who has developed a scholarly reality for Canadian community colleges and a forum for discourse on the community colleges of British Columbia. 
Growth and change have characterized the community colleges of Canada since the 1960s (Dennison \& Gallagher, 1986). In British Columbia, particularly since 1980 , change in the community college has been both rapid and dramatic (Levin, 1994). The early part of the decade gave rise to altered legislation governing the community colleges (Dennison, 1986; Mitchell, 1986) and the latter part of the decade ushered in the establishment of an new organizational formthe university-college (Levin, 1994). As the community colleges of British Columbia proceed into the 1990 s, over twenty-eight years since their inception, there remains little explanation of how these institutions function as organizations, and more specifically which groups or individuals influence their functioning. Whereas Levin and Dennison (1989) posed the question about who directed the community colleges of Canada in the 1980s and what outcomes ensued from their actions, this present study applies the same questions to the development of the community colleges of British Columbia.

An earlier study of the community colleges of British Columbia (Levin, 1994) noted alteration to the structure and processes of governance affecting these institutions. The development of the British Columbia community colleges points to an evolving structure of influence over these institutions (Levin, 1994). A shift in purpose from education and training based upon community demand, to programming based upon provincial government priorities, marked during the 1980 s a major departure for the community colleges from their mandate in the previous decades. Local structures of influence combining institutional participants and community representatives gave way to provincially oriented structures, including government and the ministry responsible for the college sector, the College-Institute Educators' Association, and the new provincial association of college governing board members and college chief executive officers, the Advanced Education Council of British Columbia. While the rationalization for this structural change was frequently cited by those involved as improved communications and co-ordination, the structural alteration following from a shift in the mandate for the colleges more likely signalled a struggle for control over institutional actions among major interest groups (Levin, 1994). Changes in legislation (e.g., the appointment of board members by the government; the development and implementation of postsecondary educational policy by the Minister), a revised method of government allocation of funds to the community colleges, and a slowdown in the provincial economy were among the alterations which enabled stakeholders, including government, to influence the actions which affect the operations and thus the development of the community colleges of British Columbia (Dennison, 1986). 
Organizational theory suggests that organizational actions are preceded by decisions which are the consequence of both intentions and the activities surrounding these decisions (Mintzberg, 1983). In the process of decision-making, actions are initiated, goals and intentions are set in motion, and the structure of influence or power and the identity of those exercising this influence or power become most apparent (Bacharach \& Lawler, 1980). The term "power" here follows the lead of Mintzberg (1983) and refers to the capacity to effect or affect organizational outcomes (Kanter, 1977; Mintzberg, 1983; Morgan, 1986). Mintzberg (1983) notes that organizational actions are the expression of organizational goals. To identify actions, therefore, is to locate organizational goals. It is expected that the identification of organizational actions will reveal not only the intentions and goals but also the actors who influence action.

The legitimation of organizational action arises out of the structure of authority (Mintzberg, 1983). Legitimate influence as well as illegitimate influence (i.e., organizational politics) may play a significant role in the actions of organizations (Mintzberg, 1983). The structure of authority for the community colleges of British Columbia is embedded in the College and Institute Act (Province of British Columbia, 1984). This Act identifies the responsible and authoritative officials or actors: the government minister, the college board, the college chief executive officer, and the college bursar. Not included in the Act but certainly considered as members of interest groups (Mintzberg, 1983), or what Coleman and Skogstad (1990a) refer to as the policy community, are college administrators, government ministry officials, college faculty, support staff, students, and the attentive public (Coleman \& Skogstad (1990a)-including the media, interested and expert individuals, and local community groups. It should be noted that the foundations of the community colleges of British Columbia had their derivations in community political activism and their educational legitimacy championed by prominent scholars from the University of British Columbia, including the president, during the early 1960 s (Dennison \& Gallagher, 1986).

Whereas Dyson (1980) argues that societies without a strong state tradition-and both Canada and the province of British Columbia fit within this group-emphasize the role of government in representing the interests of society, it might be assumed that the provincial government played a dominant role in influencing the development of the community colleges of British Columbia. The policy community (Coleman \& Skogstad, 1990a) is, however, also made up of individual actors such as community college presidents and faculty union presidents, associations including board members and community college 
presidents, and organized groups such as provincial college committees and faculty unions. If educational policy of government has an influence upon the actions of the community colleges of British Columbia, one could expect that members of the educational policy community would be influencers in the development of these colleges.

In an earlier study (Levin, 1994), forces of change in the community colleges of British Columbia, including actions and key actors, were identified. Both the direction and consequences of change were explored. Observations and conclusions arising from that study were drawn from government and institutional documents and from the literature. Would the identification of groups or individuals influential in the functioning of the community colleges differ if sources for a research investigation were those individuals involved in the actions of the colleges of British Columbia? Would an explanation emerge about how these organizations functioned if those directly involved in the development of the community colleges of British Columbia-members of the policy community (Coleman \& Skogstad, 1990a)_were solicited for their perceptions?

\section{The Study of Influence and Influencers}

What are the most significant actions of British Columbia community colleges in the 1980s? Who directed these and what were their outcomes? A group of key observers of and participants in British Columbia community collegeswhat Coleman and Skogstad (1990a) refer to as the policy community-were identified by the researcher and asked to respond to a survey questionnaire. This approach was seen as the most appropriate method of soliciting perceptions, permitting anonymity (as the respondents were not asked to identify themselves), and enabling disclosure of personal information and judgements. The selected group was noted for their participation in the development of policy for the community colleges of British Columbia; all have served on British Columbia postsecondary education committees or hold executive positions in British Columbia institutions or associations. Twenty participants were approached; ten responded to the questionnaire in the allotted time; one participant responded after the deadline; and one government official declined to complete the questionnaire, expressing a condition of bias which would not, in this official's opinion, benefit the study. Those responding included two (2) government officials, two (2) community college presidents (one from a large urban college; one from a smaller rural college), three (3) mid-level, community college educational administrators (two from urban colleges; one from a mid-size 
rural college), one (1) community college faculty member who was a former president of the College Institute Educators' Association, one (1) community college board member from a mid-size rural/urban college (who was also a member of the executive of the provincial association of college board members), and one (1) university professor noted for scholarship on the topic of British Columbia community colleges.

The questionnaire called for open-ended responses to the following questions:

1. What were the most important events or actions affecting the community colleges of British Columbia from 1980-1991?

2. Who were those individuals or groups most influential in these events or actions?

3. What were the contributing factors which gave rise to these events or actions?

4. What were the most important outcomes of these events or actions?

5. What was the impact of these events or actions upon your college or upon a specific community college with which you are familiar?

As well, the questionnaire invited additional comments from respondents.

The responses to these questions were summarized for each respondent and displayed in a table for analysis (see Appendix). These were organized within the framework of the five (5) most cited events or actions. Other cited events or actions were limited to one or at most two respondents, and these citations were neither identified nor displayed.

The limitations of this study - namely that sources are limited to ten (10) key members of the policy community - may suggest that this is an initial exploration of influence and influencers in the community colleges of British Columbia. Clearly, this study addresses the observations of leading figures or actors in the community colleges and does not address the perceptions of the rank-and-file employees of the community colleges. It is assumed, however, that some of the observations of the respondents in this study match those of the larger populations of community college participants. The College-Institute Educators' Association official who participated in this study may not represent all faculty in the colleges of British Columbia; but these views are based upon first-hand experience as not only a union leader but also a faculty member in a community college. Because of the roles of the respondents, as spokespersons 
for associations, for the government ministry responsible for postsecondary education, and for individual colleges, and as long-time actors in the community colleges of British Columbia, their observations certainly constitute more than individual perceptions.

The findings of this study, reported in the following section, are expressed as perceptions of the respondents. They are drawn directly from the written responses of the ten participants in this study. The observations are organized around the categories of actions and influencers.

\section{Actions}

Five events or actions were identified as most influential by the majority of respondents. These include, in order of most responses, the Provincial Access Report and its initiatives (1988), the Provincial government fiscal restraint program (1982-87), the creation of university-colleges (1989), the funding formula (1983-91), and the prominence of the College-Institute Educators' Association (1983-1991).

\section{Access Report}

In 1988 the provincial government, through its ministry, established a Provincial Access Committee to review educational participation in and accessibility to postsecondary education in the province of British Columbia. Respondents in this study acknowledged numerous outcomes which followed from the Access Report and its recommendations. The provincial system of community colleges experienced expansion, becoming the recipient of increased government funding for programs and facilities. Also, as a result of the focus upon access on a provincial basis, there was greater sensitivity toward and awareness of higher education in the province among not only government and community colleges, but also in the communities of the province. Special attention was directed to university transfer programs, to access for aboriginal people, for the disabled, and for women. Furthermore, the report and subsequent actions re-emphasized the need to address both literacy among the adult population of the province and opportunities for postsecondary study at the baccalaureate level.

Effects upon colleges were both numerous and varied. The initiative which led to the creation of university-colleges (dealt with in a subsequent section) brought a sense of re-vitalization to employees at those institutions which experienced increased funding. One community college, however, suffered a decline in enrollments at the second year level, the consequence of its proximity to a 
university-college. As well, the Access Report and subsequent initiatives required that some community colleges review their present mission and in some cases make appropriate alterations (e.g., greater focus upon literacy; less attention to adult basic education and vocational education for university-colleges).

\section{Fiscal Restraint}

Largely perceived as deleterious to the well-being of the community colleges of British Columbia, government fiscal restraint initiated in 1982 was a five year program aimed at reducing public sector spending. Its objectives were accomplished, but the outcomes of reduced government expenditures took their toll upon the colleges. Included in the "deterioration" of the community colleges was the lowering of morale of college employees, neglect of facilities and equipment, neglect of human resource development, curriculum planning, and institutional research, and neglect of institutional purpose.

The restraint program was seen to "unbalance" the community colleges of British Columbia. Workloads for college personnel increased; layoff or termination of employees resulted; and programs were eliminated, some passed off to the private sector. As well, there were salary disparities among the colleges (i.e., faculty at one college paid substantially lower than those occupying similar positions at other colleges). Issues of governance emerged, including participation in decision-making. But some outcomes could be seen in a positive light: productivity was increased and, in an effort to attract additional non-government funding, international education ventures flourished. Nonetheless, the consequences of the fiscal restraint program were viewed in the main as approaching an educational catastrophe.

\section{Creation of University-Colleges}

As an outcome of the Access Report and its recommendations, three provincial community colleges were designated as "university-colleges" in 1989. These three-Cariboo, Malaspina, and Okanagan-were intended to develop toward baccalaureate degree-granting status. In the intervening years, the provincial universities were to co-operate with the university-colleges by granting their degrees to students who fulfilled baccalaureate requirements at one of these colleges.

The creation of the university-college led to increased accessibility to third and fourth year university programming in the province, particularly for those in the communities served by the three university-colleges. These institutions experienced an increase in their funding from government, not only to support 
operating costs for new programs, but also for the expansion of facilities to accommodate students. Other outcomes of the creation of university-colleges included the loss of second year at a community college adjacent to a university-college and a perception that the introduction of these institutions led to a more differentiated postsecondary educational system in British Columbia.

\section{Formula Funding}

Subsequent to the government fiscal restraint program, the provincial ministry responsible for the community colleges established in 1983 a formula for the allocation of government funds to the colleges (continuing until the present time). Respondents, while acknowledging the influences of this funding formula, were not consistent in their perceptions. One respondent noted that the formula created greater equity in funding; another that the application of the formula led to unfair treatment of some colleges. Government officials who responded suggested that as a result of the formula, community colleges pressured government to increase individual institutional allocations; and as a result of this process, colleges showed greater awareness about the costs of programs. Others noted that the formula led to a reduction of programs and that some individual community colleges suffered from a continual shortage of resources as a consequence of the formula.

\section{The Prominence of the College-Institute Educators' Association (CIEA)}

The College-Institute Educators' Association (CIEA), established by college and institute faculty unions in the late $1970 \mathrm{~s}$, gained considerable prominence in the early $1980 \mathrm{~s}$ in the wake of both government fiscal restraint and alterations to legislation governing the colleges. In the late 1980s and into 1990, CIEA increased its role in community college collective bargaining. It is in the arena of collective bargaining and salary negotiations that CIEA is perceived to have had the most influence over the community colleges of British Columbia. Although one perception is that CIEA achieved a position of influence, and even acceptability, in shaping community college development, the more frequent perception is that the role of CIEA has been a less than positive force in community college affairs. Included as the perceived effects of CIEA are increased adversarial relations at the colleges, greater stress upon college resources (e.g., as a consequence of high wage settlements), and a decrease in the stability of individual institutions. 


\section{Influencers}

Those who were identified as the major influencers of the five most significant actions or events from 1980-1991 included the following groups: the British Columbia government, the provincial cabinet of the government in power, the Treasury Board of the provincial government, officials of the Ministry of Advanced Education, Training, and Technology, community college presidents, community college boards, community groups, advocacy committees, the provincial association of faculty unions and individual community college faculty unions. Individual members of the policy community (Coleman \& Skogstad, 1990a) included the Premier of the province, the Minister of Advanced Education, Training, and Technology, the president of a provincial university, an advisor to the Premier of the province, a deputy Minister of Advanced Education, Training, and Technology, two Assistant Deputy Ministers of Advanced Education, Training, and Technology, an official in the ministry, community college presidents (present and former), and presidents and directors (present and former) of the College-Institute Educators' Association. Both government and more specifically the government Ministry of Advanced Education, Training, and Technology, however, are perceived by the majority of respondents as the most influential parties in affecting the community colleges of British Columbia. It should be noted that the study encompassed a period where there were three different provincial premiers. Only one, Premier Bill Bennett, was specifically identified as an influencer.

\section{Who is Directing the Community Colleges of British Columbia?}

Clearly, government, whether at the level of the Premier, the Cabinet, or the Ministry responsible for postsecondary education in the province of British Columbia, was perceived by respondents to be the dominant influencer for the community colleges of the province. Such influence appears to be in the direction of public interests or public opinion. The Access Report and its initiatives were the consequences of a large and unmet demand for postsecondary education, particularly baccalaureate opportunities. Funding restraints during the 1980 s were carried out with a perceived mandate from the electorate to limit public sector spending; and the creation of university-colleges in Nanaimo, Kamloops, and Kelowna, rather than in the Lower Mainland of British Columbia where demand for student places was greater, was a response to local lobbying pressures in the three communities. It was as well a vehicle for both 
increasing postsecondary participation rates and solving the limits on third and fourth year enrollments in the province without placing enormous strain upon public expenditures (Levin, 1994).

Government actions led to significant outcomes. Some of these, such as the Access initiatives, were viewed in a positive light. Others, such as fiscal restraint, were viewed negatively. Government, whether as a group of Ministry officials or as individuals such as the Premier of the province, dominates as the perceived influencer in the actions of the community colleges of British Columbia. Evidently, government directed the community colleges of British Columbia through its decisions; and these led to such actions as fiscal restraint, access initiatives, and the creation of university-colleges. While community college presidents were noted as the precipitators of a funding formula, their overall role either as individuals or as a formal group was not judged to be highly influential. Other community college officials, including boards, administrators, or faculty, were not identified as major influencers of the actions of community colleges. The College-Institute Educators' Association was viewed as influential only in its role as a provincial faculty association involved in community college collective bargaining.

Given the formal structure of authority for the community colleges of British Columbia, enshrined in legislation (Province of British Columbia, 1984), the role of government should not be surprising. However, others with responsibility for the community colleges and identified in the legislation-governing boards, college presidents, and bursars-were not identified as influential, at least not to the same degree as government. Furthermore, other groups who might be expected to have influence-administrators' provincial committees and CIEA, two sectors established to exert influence-were not identified as influential by respondents. Nor was there identified individual leadership from the community college sector in the form of a community college president who was able to exert influence over the actions of the community colleges of British Columbia. In a period where organizational excellence is equated with leadership, this omission is disquieting, especially in light of the many appeals in the literature for educational leadership in the postsecondary sector. In this study, both government and community college officials view government as the key influencer in actions relevant to the community colleges. This view is supported by the majority of all respondents.

One expected but missing influential action can be noted in this study: the amendments to the legislation which governs the community colleges of British Columbia. These amendments occurred in the summer of 1983 (and the 1984 
act incorporates these). The impact of this legislation has been discussed elsewhere (Dennison, 1986; Mitchell, 1986). This legislation gave authority to the Minister of Advanced Education, Training, and Technology to appoint all community college board members (who in turn appoint community college presidents) and to develop and direct all policies for the community colleges. Such legislation gave the Minister authority to implement Provincial government initiatives (e.g., restraint program) and Ministry sanctioned reports (e.g., Access Report). This legislation enabled the government to direct the community colleges. Surprisingly, only one respondent referred to these amendments, and then only as a contributing factor to the main action involving the prominence of CIEA.

\section{Implications}

In another study of power and influence in the community colleges of British Columbia (Levin, 1994), not only government but also college presidents and college boards were identified as the primary groups influential in the actions of British Columbia community colleges. That study relied upon the literature and relevant institutional and government documents as sources. Key observers and participants (the policy community) were not sources for that study. The disparity between the findings of that study and this present one suggests that perceptions are not consistent with documentary evidence and the literature. If the participants in the community colleges of British Columbia perceive that government is the dominant influencer, the persuasiveness of the documentary evidence and the literature may be limited. It may be that those in and around the community colleges of British Columbia have constructed a social reality in which they act consistent with the perception that government directs the community colleges.

If government and its agency are viewed as directing the community colleges of British Columbia, then the missions and purposes of those colleges may have developed beyond their communities and been replaced by the priorities of government. This same condition has been noted for Canadian community colleges in a national study (Levin and Dennison, 1989). Community college officials, including college board members, presidents, and administrators, may no longer look to their communities for direction, but rather follow the policies and recommendations of government and its agency. It may be that community colleges see themselves as unable to solve their own problems - which may emanate from government - or to pursue their own aspirations. That is, the aspirations or values of individual colleges may not be compatible with the 
priorities of government. One would expect that in such a structure of influence and authority, where the government and its agency are viewed as a dominating influencer over the actions of the colleges, the relationship between the community colleges and government would be adversarial or antagonistic. The structure, where government is viewed as the sole dominant influencer in the actions of the community colleges of British Columbia, is a power structure (Bacharach \& Lawler, 1980) where the power of government, its ability to affect organizational outcomes, is relative to the powerlessness of the community colleges and college participants. In addition, as the community colleges are fiscally dependent upon government, one would expect to see British Columbia community colleges functioning as government departments or agencies; but the history of the British Columbia community colleges suggests a fairly high degree of autonomy (Dennison \& Gallagher, 1986), with government initiatives not always fulfilling their intentions in the community colleges (Mitchell, 1986).

How do the community colleges function, then? Based upon this study, it may be that community colleges operate within an environment of perceived direction, even attempted coercion, from government. The perception and acceptance of government as the dominant influencer removes responsibility for action from community college officials. It means that community colleges can rationalize change or lack of it, depending on the context, by pointing to government as the party responsible. Thus external pressures justify change (or stasis) within a college, and government's response to the external environment, including the economy, is reason enough for colleges to follow its lead, whether the issue is wage settlements, or educational programming, or personnel practices. It may be, however, that the perception of government as the dominant influencer in the actions of the community colleges of British Columbia is focussed upon the community colleges as a whole or upon a community college (or postsecondary) system and not upon individual community colleges where the ability to affect organizational outcomes may reside with internal influencers, not external ones. 
1. Advocacy groups (ABEBC: ASEBC)

2. Minister (Hagan) \& Senior Ministry personnel

3. Hagen, Fisher, Strangway, Mullins, Les Bullen, J. Watson

4. Ministry officials, Access Committees, Cabinet

Access Community pressure from interio

Initiatives cities; handful of faculty, one College president and a Ministry official

7. Ministry and Premier

8. Grassroots

10. Hagen, Gallagher, Morin, COP members of Access Committee
1. Awareness of disadvantaged groups

2. Media coverage of unmet demands in Lower Mainland public support for education: government recognition of education as investment

3. Public pressure (Socred ranks) to improve local access

4. Related research on pse, improved economy, political priority for pse, demand for degree stream programs

6. Technological change; increased interest in academic subjects

7. Limited access to degree programs

8. Increased awareness for equal opportunities

9. Need for places in university programs

10. Attempts to buy back votes by politicians
1. Growth in ASE, UT, programs for natives and more campuses at col leges

2. Increase in funded FTE's; new facilities

3. Increase in investment in colleges \& universities; greater sensitivity for accessibility; U-C's; expansion of universities and colleges; F.V. movement

4. Some recovery from restraint, expansion of seats, concern among vocational \& career faculty \& advisory committees

7. Literacy initiative; creation of university-colleges

9. Degree granting at Okanagan, Cariboo, Malaspina; UNBC;

increased opportunities for natives, disabled, abled, illiterate, facilities growth

10. Two year increase in funding especially captial
1. College board, Admin. Faculty \& community more sensitive to needs of disadvantaged

2. Loss of 2nd year students to university-college in adjacent region

3. Helped college to re-focus its mission

9. Additional spaces for $3 \mathrm{rd} \&$ 4th year, captial expansion \& renovations; support for programs for disadvantaged; support for innovative degree program

10. Mini-boom, growth; helped to return energy to institution 
Appendix (continued)

Event/

Action

INFLUENCERS

CONTRIBUTING FACTORS

2. Increases in school district salaries; government agenda to

2. Premier and Cabine

3. Premier (Bennett), Government \& Norman Spector

4. Cabinet

5. Provincial Government

6. Provincial Government

8. Socred Government

Fiscal

10. Government, Bennett

Restraint

$$
\text { control costs }
$$

3. State of economy; philosophy of government

4. Depressed state of provincial world-wide economies

5. Recession

10. Recession
1. Community citizens

2. Minister (Hagan) \& Senior Ministry personnel

3. Mullins, Watson, others

Creation 7. Deputy Minister \& Ministry

of 8. Local communities

University 10. Non-urban colleges; community -Colleges demands
2. Media coverage of unmet demands; public support for education; government recognition of education as investment

3. Solve access problem without creating more pse institutions

7. Need for better access to degree programs outside Vancouver \& Victoria

8. Government need for popularity

10. Funding realities; low pse par-

ticipation rates; international

economies

\section{OUTCOMES}

IMPACT ON A

SPECIFIC COLLEGE

2. Morale lowered; increase in salary disparaties

3. Movement to privatization; unbalancing of institutions; governance issues

4. Increased workloads, layoffs, equipment/facilities deterioration, incentive for innovation \& productivity

5. Neglect of HRD, Curriculum Planning; depression for Fac. \& Admin.; neglect of purpose; rise in International Education

6. Improved efficiency; assessment of purpose \& programs; greater interinstitutional co-operation; strains \& stress on system \& within colleges

10. Starved system; institutionalized acceptance of inadequate funding

1. Increased access to 3 rd \& 4 th year programs

2. Increase in funded FTE's; new facilities

3. Differentiated pse system

7. 3 University-colleges with varying problems

10. 3 University-colleges created \& F.V.C. wish to join
2. Closure of D. Thompson University Centre and significant reductions in funding

3. Bunker mentality; spend postpone important issues; problem now in vocational \& technical education, obsolete equipment, unfair pay to personnel

5. Devastating effects upon college

8. Physical deterioration \& moral deterioration

10. Lean operations in key areas under-financed buildings; no R \& D

1. Promotion/Initiation by college to become universitycollege

2. Loss of 2nd year students; introduction of teacher education and improved local opportunities

3. Not directly affected

10. Little impact although Valley decision may affect scarce resources unwisely, 
Appendix (continued)

\begin{tabular}{|c|c|c|c|c|}
\hline $\begin{array}{l}\text { Event/ } \\
\text { Action }\end{array}$ & INFLUENCERS & $\begin{array}{c}\text { CONTRIBUTING } \\
\text { FACTORS }\end{array}$ & OUTCOMES & $\begin{array}{c}\text { IMPACT ONA } \\
\text { SPECIFIC COLLEGE }\end{array}$ \\
\hline $\begin{array}{l}\text { Prominence } \\
\text { of CIEA \& } \\
\text { Provincial } \\
\text { Bargaining }\end{array}$ & $\begin{array}{l}\text { 3. Ed Lavalle \& directors since } 1988 \\
\text { 4. CIEA, local faculty unions, col- } \\
\text { lege boards } \\
\text { 6. CIEA } \\
\text { 9. Paul Ramsey \& Ed Lavalle } \\
\text { 10. Lower Mainland Faculty } \\
\text { Association \& CNC; restraint } \\
\text { pressures; CIEA presidents }\end{array}$ & $\begin{array}{l}\text { 3. Strategy to become voice and } \\
\text { representative of college faculty } \\
\text { 4. Differential between salary } \\
\text { increases \& inflation; reaction } \\
\text { to increased student loads; con- } \\
\text { cern for renewal \& p.d. among } \\
\text { "aging" faculty } \\
\text { 5. Co-ordinated bargaining } \\
\text { 6. Restraint } \\
\text { 9. Gain in power, control over } \\
\text { governance as aim } \\
\text { 10.27 Bills of } 1983 \text {; need for } \\
\text { provincial voice; bargaining dif- } \\
\text { ficulties }\end{array}$ & $\begin{array}{l}\text { 3. Greater influence in shaping of col- } \\
\text { lege } \\
\text { 4. Stress upon conventional delivery } \\
\text { systems, upon personnel relations } \\
\text { and on budgets } \\
\text { 5. More aggressive bargaining tactics; } \\
\text { dominance of trade unions over pro- } \\
\text { fessionalism } \\
\text { 9. Salary negotiations at college, diffi- } \\
\text { cult and adversarial } \\
\text { 10.CIEA accepted by media, govern- } \\
\text { ment, \& others as voice of pse from } \\
\text { faculty perspective }\end{array}$ & $\begin{array}{l}\text { 3. College now only one element } \\
\text { in CIEA strategy } \\
\text { 5. Devastating upon colleges, } \\
\text { high wage settlements } \\
\text { 9. Arbitration; threat of future } \\
\text { strikes } \\
\text { 10. No major effects; contributed } \\
2 \text { presidents }\end{array}$ \\
\hline
\end{tabular}

Mainland Presidents

Fisher as ADM

. Ministry officials \& Council of Principals

Ministry Staff

Ministry personnel - McCandless, Fisher \& Treasury Board

3. Ed Lavalle \& directors since 1988

CIEA, local faculty unions, col-

Provincial 9. Paul Ramsey \& Ed Lavalle

. Lower Mainland Faculty

Association \& CNC; restrain

pressures; CIEA presidents
Belief by some Presidents that were capricion and inequitable

was equitable funding

inequitable, lacking clear and objective criteria

Inequities in funding; prospect of limited resources

Strategy to become voice and

\& inflation; reaction

increased student loads; con"aging" faculty

Co-ordinated bargaining

Restraint

governance as aim

provincial voice; bargaining difficulties
Different institutions now treated

sure to increase allocations, claims of

uniqueness to justify exception cost programs

Budgetary restraints; reduction of

Greater influence in shaping of col-

More aggressive bargaining tactics;

Salary negotiations at college, diffi-

as voice of pse from
3. College now only one element high wage settlements strikes

No major effects; contributed 2 presidents 


\section{References}

Bacharach, S. \& Lawler, E. (1980). Power and politics in organizations. San Francisco: Jossey-Bass Publishers.

Coleman, W. \& Skogstad, G. (1990a). Policy communities and policy networks: A structural approach. In W. Coleman \& G. Skogstad (Eds.), Policy communities and public policy in Canada: A structural approach (pp. 14-31). Mississauga, Ontario: Copp Clark Pitman Ltd.

Coleman, W. \& Skogstad, G. (1990b). Conclusion. In W. Coleman \& G. Skogstad (Eds.), Policy communities and public policy in Canada: A structural approach (pp. 312-327). Mississauga, Ontario: Copp Clark Pitman Ltd.

Dennison, J. (1986). Some aspects of government policy towards community colleges in British Columbia: 1982-86. Journal of Educational Administration and Foundations.

Dennison, J. \& Gallagher, P. (1986). Canada's community colleges. Vancouver: University of British Columbia Press.

Dennison, J. \& Levin, J. (1989). Canada's community colleges in the nineteen eighties: Responsiveness and renewal. Toronto: Association of Canadian Community Colleges.

Dyson, K. (1980). The state tradition in Western Europe. Oxford: Basil Blackwell.

Kanter, E. (1977). Men and women of the corporation. New York: Basic Books.

Levin, J. (1994). Power in the British Columbia community college. B.C. Studies, forthcoming.

Levin, J. \& Dennison, J. (1989). Responsiveness and renewal in Canada's community colleges: A study of change in organizations. Canadian Journal of Higher Education, 19(2), 41-57.

Mintzberg, H, (1983). Power in and around organizations. Englewood Cliffs, New Jersey: Prentice-Hall.

Mitchell, A. (1986). Administrators' perceptions of implementing provincial policy on community college governance in British Columbia. Unpublished doctoral dissertation. University of British Columbia.

Morgan, G. (1986). Images of organization. Beverly Hills: Sage Publications.

Province of British Columbia (1984). College and institute act. Victoria: Queen's Printei. 